\title{
DEAD MEAT
}

\author{
Interactive art.
}

\section{BY POLENTH BLAKE}

$\mathrm{T}$ True art is seamless. That's why I crafted my new gallery out of meat. Patrons squelched around the entrance hall in plastic coats and boots. One man touched the walls gingerly. His hand came away red with blood.

"Welcome to Dead Meat II," a voice greeted him from the wall. The voice holes lined the entrance room, each with its own set of vocal cords and lungs. They'd been modelled after mine. Although the tone was right, the organic quality was missing. Higher functions needed the computer's control and it never quite got it.

The entrance had information on the original Dead Meat. It had been a stroke of genius, if I do say so myself. Meat bricks around a metal frame. I'd fused the meat together with transglutaminase, so it looked like it'd grown as one solid lump.

Genius, but temporary. All meat goes bad in the end. Still, Clarissa Brookes was a worldwide name before the last piece rotted away. I had no trouble getting sponsors for this gallery.

The door to the first section opened as I approached. Far superior to any mechanized door. The muscles could open it slowly for the casual wanderer or pull back quickly when a child ran through. The door understood. Cold metal and plastic couldn't mimic that.

My sponsors had insisted on displays of my older work. I'd resisted at first, but I came around to seeing the merit. My patrons learnt with me. Paintings of daisies growing out of women. An elephant's head flowed into a whale's body. The works were crude, but the concept of seamless design was lurking in the brush strokes.

“They're a bit creepy, aren't they?" a woman noted to her companion.

I resisted commenting. Some patrons were slower learners than others.

For my first sculpture, I'd sewn the front ends of two sheep together. The fleece was arranged to cover the seams, but I knew that they were there. Stitches are still stitches, no matter how well you hide them.

Blood oozed from the ceiling more freely in the next room. A few splashes landed on the hood of one patron.

After a whispered conversation with his partner, they headed back towards the entrance.

\section{ONATURE.COM}

Follow Futures on

Facebook at:

go.nature.com/mtoodm
I pitied them for their squeamishness. I'd refused the plastic coverings, preferring to wander the halls in a mini skirt and tank top. I wanted to feel the blood on my skin.

Most of my middling work was inconsequential. The same old designs, as I struggled to find my way. I ignored the pieces in favour of the patrons. A child watched the floor, pressing his foot against the flesh to see it ooze. He realized that the true art was the building. It made it all worthwhile.

A man fainted and nicked the wall with his watch as he slumped into it. Pores opened in the floor to reabsorb the blood from the cut, while the edges of the tear pulled together. Designing the repair nanobots had been the hardest part. A true immune system would react with or without control, but the nanobots needed the computer. They were the final seam in the construction. For the next Dead Meat, I'd do away with the last of the machinery.

The doors jerked open. Two security guards hurried through, in the manner of people who don't want to panic the patrons. The door muscles trembled in response.

I followed the guards, resting a reassuring hand on the doorframe as I passed.

Muffled shouts came from farther in the gallery. No doubt one of the protestors, spouting about abominations of nature and other nonsense. As though a living gallery was worse than cars and aeroplanes. At least my work would merge back into the earth in the end.

One of the guard's radios hissed out a message. Too quiet to hear, but the guards were running now.

A dull boom reverberated through the meat. Every door muscle spasmed.

I sprinted past the guards towards the sound. A stream of blood flowed from a torn door muscle, but it was minor compared with the damage in the room. It had been a precise attack. The bomber set it off by the wall nearest the control centre, taking out the meat and a chunk of the computer. The muscles would survive on their own for a while, but without a computer to coordinate repair, Dead Meat II would bleed to death.

The guards arrived behind me. "Ma'am?" one asked.
"Get the back-up systems."

They left and I turned my attention to the wounds. Even without control, the nanobots would run a basic routine of sealing meat to meat. That was something I had. The bomber, and several guards, were splattered over the walls. I picked up a mangled arm and placed it against the bleeding door muscle, until the arm fused over the damage.

I started the same process on the large hole, but before long the blood was up to my ankles. Too much for the pores to take back in.

"It'll be an hour, maam," a guard reported from the door, with a glance at the arm lodged there.

When I was younger, in the days when I thought that painting was the ultimate expression, I'd have been angry. Now, anger was just another seam, keeping me from what I had to do. I climbed into the wound and rested my head against the damaged flesh. The guard's shouts faded as my wound healed around me.

My eyes opened in every room. I marvelled at the seamless perfection of the artwork wandering my corridors, in their shades of wonder and fear.

In my entrance room, I greeted my art. "Welcome to Dead Meat III." -

Polenth Blake (www.polenthblake.com) lives in England with her pet cockroaches, and prefers her meat cooked. 